\title{
Phosphorus(III) Double Bond Systems, Carbene and Alkene Analogues. The Electronic Structure of Imino- and Methylene-phosphanes
}

\author{
E. Niecke," D. Gudat,a W. W. Schoeller,"a and P. Rademacherb \\ a Fakultät für Chemie der Universität Bielefeld, 4800 Bielefeld 1, Postfach 8640, Federal Republic of Germany \\ b Fachbereich Chemie der Universität Essen, Universitätsstrasse 5-7, 4300 Essen, Federal Republic of \\ Germany
}

Frontier orbital assignment in iminophosphanes is carried out by utilizing a linear relationship between differences in optical transitions and ionisation potentials confirming the ambident reaction behaviour of these compounds.

According to quantum chemical investigations phosphorus(III) double bond systems should show ambident reaction behaviour, ${ }^{1}$ owing to a differing sequence of frontier orbitals $\left[\sigma / \pi^{*}\right.$ (carbene) vs. $\pi / \pi^{*}$ (alkene) $]$ in these systems. Here we report on an experimental verification of this fundamental concept. It will be shown that iminophosphanes react with hexafluoroacetone (HFA) to form either the four-membered ring system (A) or the three-membered ring system (B) (Scheme 1), depending on the substituents $R^{1}$ or $\mathrm{R}^{2}$, and in agreement with the measured spectra for these compounds.

The iminophosphanes (1)-(5) as well as the isoelectronic methylenephosphanes (6) and (7) show two energetically low-lying ionization potentials $(<10 \mathrm{eV})$ (Table 1). The higher-lying bands $(>10 \mathrm{eV})$ are broad and not resolvable. The u.v. spectra show two absorption bands below 50000 $\mathrm{cm}^{-1}$ (Table 1). According to their intensities these are assigned as $n \rightarrow \pi^{*}$ or $\pi \rightarrow \pi^{*}$ optical transitions. While on the basis of the photoelectron (p.e.) spectra an unequivocal

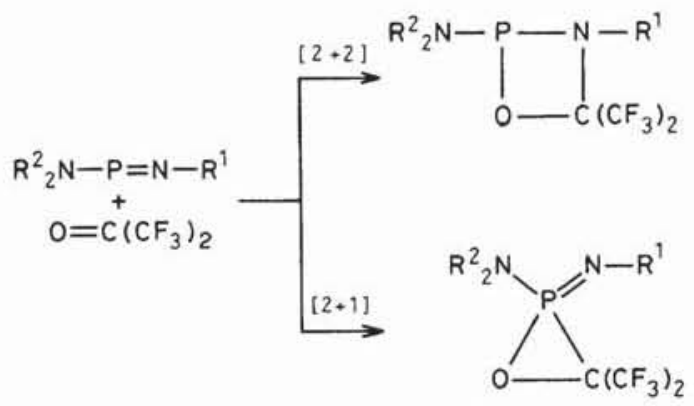

Scheme 1. (A), $\mathrm{R}^{1}=\mathrm{Bu}^{\mathrm{t}}, \mathrm{R}^{2}=\mathrm{Pr}^{\mathrm{i}} ;(\mathrm{B}), \mathrm{R}^{1}=\mathrm{SiMe}_{3}$ or $\mathrm{Bu}^{\mathrm{t}}, \mathrm{R}^{2}=$ $\mathrm{SiMe}_{3}$. assignment of the order of orbitals is not possible, it becomes feasible utilizing the linear relationship ${ }^{2}$ between differences in u.v. data and ionisation potentials among the same type of molecular structures. In the correlation (Figure 1) the methylenephosphanes are not included, because the chromophores $(\mathrm{C}=\mathrm{P}$ vs. $\mathrm{P}=\mathrm{N} \pi$-system $)$ are different. For (5), $\Delta$ i.p. $=$ $0.09 \mathrm{eV}$, and the n-orbital can be placed above $(\bullet)$ or below (0) $\pi$ (see Figure 1); for (1)-(4) the n-orbital is definitely above the $\pi$-orbital.

According to the correlation (1) occupies an exceptional position; its n-orbital is considerably above $\pi$. The introduction of an amino group lifts the $\pi$-orbital, while the n-orbital is

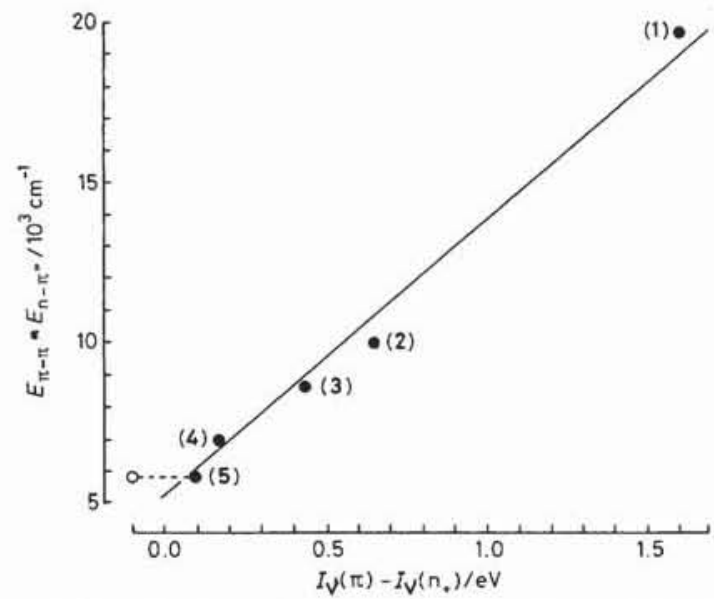

Figure 1. Relation between energy differences of $\mathbf{n}$ and $\pi$ ionisation potentials and corresponding electron excitations in the iminophosphanes (1)-(5).

Table 1. Vertical ionization potentials, $I_{\mathrm{v}, \mathrm{i}}$ (in $\mathrm{eV}$ ) and optical transition energies $E$ (in $\mathrm{cm}^{-1}$ ) with corresponding extinction coefficients $\varepsilon_{\max }$. (in $1 \mathrm{~cm}^{-1} \mathrm{~mol}^{-1}$ ) of imino- and methylene-phosphanes $\mathrm{R}^{1}-\mathrm{P}=\mathrm{X}-\mathrm{R}^{2}$, a

$$
\mathrm{R}^{1}-\mathrm{P}=\mathrm{X}-\mathrm{R}^{2}
$$

\begin{tabular}{|c|c|c|c|c|c|c|c|}
\hline & $\mathrm{x}$ & $\mathbf{R}^{1}$ & $\mathrm{R}^{2}$ & $I_{v, 1}$ & $I_{\mathrm{v}, 2}$ & $E_{\pi \cdot \pi} \cdot\left(10^{-2} \varepsilon\right)$ & $E_{\mathrm{n} \cdot \pi^{*}} \cdot\left(10^{-2} \varepsilon\right)$ \\
\hline$(\mathbf{1})^{\mathrm{b}}$ & $\mathrm{N}$ & $\mathrm{Bu}^{\mathrm{t}}$ & $\mathrm{Bu}^{\mathrm{t}}$ & $8.1\left(\mathrm{n}_{+}\right)^{\mathrm{h}}$ & $9.7(\pi)^{\mathrm{h}}$ & $42920(120)^{i}$ & $23200(2.5)^{i}$ \\
\hline (2) & $\mathrm{N}$ & $\mathrm{N}\left(\mathrm{SiMe}_{3}\right)_{2}$ & $\mathrm{SiMe}_{3}$ & $8.10\left(\mathrm{n}_{+}\right)$ & $8.75\left(\pi_{2}\right) j$ & $38170(64)$ & $28250(2.7)$ \\
\hline (3) d & $\mathrm{N}$ & $\mathrm{N}\left(\mathrm{SiMe}_{3}\right)_{2}$ & $\mathrm{Bu}^{t}$ & $8.05\left(\mathrm{n}_{+}\right)$ & $8.48\left(\pi_{2}\right)$ & $37450(56)$ & $28140(2.0)$ \\
\hline (4) $\mathrm{d}^{\mathrm{d}}$ & $\mathrm{N}$ & $\mathrm{N}\left(\mathrm{Bu}^{t}\right) \mathrm{SiMe}_{3}$ & $\mathrm{Bu}^{\mathrm{t}}$ & $7.89\left(\mathrm{n}_{+}\right)$ & $8.06\left(\pi_{2}\right)$ & $35970(49)^{\mathrm{k}}$ & $28990(2.1)^{\mathrm{k}}$ \\
\hline$(5)^{d}$ & $\mathrm{~N}$ & $\mathrm{~N}\left(\mathrm{Pr}^{\mathrm{i}}\right)_{2}$ & $\mathrm{Bu}^{\mathrm{t}}$ & $7.90 \mathrm{~g}$ & 7.998 & $35340(46)$ & $29410^{1}$ \\
\hline$(6)^{e}$ & $\mathrm{CH}$ & $\mathrm{But}^{\mathrm{t}}$ & $\mathrm{Bu}^{\mathrm{t}}$ & $8.74(\pi)$ & $8.95(n)$ & $42550(59)$ & $34360(2.1)$ \\
\hline$(7)^{f}$ & $\mathrm{CH}$ & $\mathrm{N}\left(\mathrm{SiMe}_{3}\right)_{2}$ & $\mathrm{Bu}^{\mathrm{t}}$ & $8.01(\pi)$ & $8.96(\mathrm{n})$ & $39060(12)$ & $35590(8.6)$ \\
\hline
\end{tabular}

a Experimental: p.e. spectra of (2)-(7): Leybold-Heraus UPG-200 instrument, direct injection, calibration with Ar/Xe. The vertical i.p.s are the average of several measurements; accuracy $\pm 0.05 \mathrm{eV}$; u.v. spectra: gas phase, at $55^{\circ} \mathrm{C}$; solution, in n-heptane; wavelength, $\pm 1 \mathrm{~nm}$; extinction cofficient $\pm 10 \%$. ${ }^{b}$ See ref. 3. ${ }^{\mathrm{c}}$ See ref. 4 a. ${ }^{\mathrm{d}}$ See ref. $4 \mathrm{~b}$. ${ }^{\mathrm{e}}$ See ref. $5 \mathrm{~b}$. ${ }^{\mathrm{t}} \mathrm{E}$. Niecke, D.-A. Wildbredt, and W. W. Schoeller, Angew. Chem., 1981, 93, 119; Angew. Chem., Int. Ed. Engl., 1981, 20, 131. \& $\mathrm{n}_{+}$or $\pi_{2}$; no unequivocal assignment possible. h $\mathrm{S}$. Elbel, A. Ellis, E. Niecke, H. Egsgaord, and L. Carlsen, J. Chem. Soc., Dalton Trans., 1985, 879. ' Measured in the gas phase. 1 Highest occupied $\pi$ orbital of the heteroallylic system. $k$ For the u.v. data see also ref. $4 \mathrm{~b}$. ' Shoulder. 
J. CHEM. SOC., CHEM. COMMUN., 1985

essentially unaffected. Thus, in the $\mathrm{N}$-alkylated aminoiminophosphane (5) the orbitals $n$ and $\pi$ are almost equal in energy. Successive replacement of the alkyl groups by (electron attracting) silyl groups $[(5)<(4)<(3)<(2)]$ increases the $\pi$-ionization potential. For the methylenephosphanes $(6)$ and (7) the assignment of the i.p. data is obtained by comparison with the spectra of the isoelectronic structures (1) and (2). In contrast to the iminophosphanes, in (6) and (7) the orbital sequence is reversed ( $\pi$ above $\sigma$ ), in agreement with the theoretical findings. ${ }^{1}$

In line with these spectroscopic investigations is the reaction behaviour of the imino- and methylene-phosphanes. The carbene analogue (1) undergoes $[2+1]$ self-dimerisation; ${ }^{3}$ in contrast, (5) already shows alkene reactivity and yields the corresponding $[2+2]$ cycloadduct. The latter pathway $([2+$ 2] cycloaddition) is well established for kinetically labile methylenephosphanes. ${ }^{6}$ [This reaction pathway is also observed for the iminophosphanes (1) and (2) in the presence of small amounts of Lewis acids. ${ }^{5}$ ] With HFA (2) yields the ring $(B)^{7}$ while (5) prefers the formation of $(A) . \dagger$ Borderline cases are (3) and (4). The former adds slowly to HFA $\ddagger$ with formation of (B) while (4) does not react at all. $\$$

$\dagger$ (A): b.p. $28-30^{\circ} \mathrm{C}$ at 0.1 Torr; m.s. $(70 \mathrm{eV}): \mathrm{m} / z 368\left(8 \%, M^{+}\right)$and $148\left(100 \%, \mathrm{Pr}_{2} \mathrm{NPOH}^{+}\right)$; n.m.r. $(\delta$ in p.p.m.; $J$ in $\mathrm{Hz}): \delta\left({ }^{31} \mathrm{P}\right)$ (relative to external $\left.\mathrm{H}_{3} \mathrm{PO}_{4}\right) 181.7 ; \delta\left({ }^{19} \mathrm{~F}\right.$ ) (relative to external $\mathrm{CFCl}_{3}$ ) $-74.7\left({ }^{4} J_{\mathrm{FP}} 20.9\right)$ and $-76.4\left({ }^{4} J_{\mathrm{FP}}<0.5,{ }^{4} J_{\mathrm{FF}} 8.3\right) ; \delta\left({ }^{13} \mathrm{C}\right) 20.0$ $\left({ }^{3} J_{\mathrm{CP}}<0.5\right), 23.1 \quad\left({ }^{3} J_{\mathrm{CP}}<0.5\right), 26.4\left({ }^{3} J_{\mathrm{CP}} 11.0\right), 27.7\left({ }^{3} J_{\mathrm{CP}} 22.1\right)$ $(\mathrm{CHMe}) ; 29.6\left(\mathrm{CMe}_{3}\right) ; 43.6\left({ }^{2} J_{\mathrm{CP}}<0.5\right), 45.6\left({ }^{2} J_{\mathrm{CP}} 30.5\right)\left(\mathrm{CHMe}_{2}\right)$; $53.2\left({ }^{2} J_{\mathrm{CP}} 6.8\right)\left(\mathrm{CMe}_{3}\right) ; 89.6\left({ }^{2} J_{\mathrm{CF}} 33.6,{ }^{2} J_{\mathrm{CP}} 2.0\right)\left[C\left(\mathrm{CF}_{3}\right)_{2}\right] ; 121.0$ $\left({ }^{1} J_{\mathrm{CF}} 291.0,{ }^{3} J_{\mathrm{CP}} 9.0\right), 123.8\left({ }^{1} J_{\mathrm{CF}} 291.9,{ }^{3} J_{\mathrm{CP}} 8.1\right)\left[\mathrm{C}\left(\mathrm{CF}_{3}\right)_{2}\right]$.

$\ddagger 15 \%$ reacted after 1 week at $40^{\circ} \mathrm{C}, \delta\left({ }^{31} \mathrm{P}\right)-60.5$ p.p.m.

$\S$ No reaction after 2 weeks at $40^{\circ} \mathrm{C}$.
On the basis of our investigations, in iminophosphanes their carbenic character changes towards an alkenic character, depending on the substituents $R^{1}$ and $R^{2}$. Predictions about the reactive behaviour of this class of PIII double bond systems can be made on the basis of their spectroscopic data, in particular their photoelectron spectra. ${ }^{8}$

The authors thank the Deutsche Forschungsgemeinschaft and the Fonds der Chemischen Industrie for support, and Professor V. Röschenthaler, Universität Bremen, for a gift of HFA.

Received, 12th March 1985; Com. 333

\section{References}

1 W. W. Schoeller and E. Niecke, J. Chem. Soc., Chem. Commun., 1982,$569 ;$ W. W. Schoeller, manuscript in preparation.

2 E. Haselbach and A. Schmelzer, Helv. Chim. Acta, 1971, 54, 1575.

3 E. Niecke, R. Rüger, and W. W. Schoeller, Angew. Chem., 1981, 93, 1110; Angew. Chem., Int. Ed. Engl., 1981, 20, 1034.

4 (a) E. Niecke and W. Flick, Angew. Chem., 1973, 85, 586; Angew. Chem., Int. Ed. Engl., 1973, 12, 585; (b) O. Scherer and W. Glässel, Chem. Ber., 1977, 110, 3874.

5 (a) E. Niecke, W. Flick, and S. Pohl, Angew. Chem., 1976, 88, 305; Angew. Chem., Int. Ed. Engl., 1976, 15, 309; (b) E. Symalla, Diplomarbeit, Bielefeld, 1984; E. Niecke and E. Symalla, manuscript in preparation.

6 R. Appel, F. Kindi, and I. Ruppert, Angew. Chem., 1981; 93, 771; Angew. Chem., Int. Ed. Engl., 1981, 20, 731.

7 V. Röschenthaler, K. Sauerbrey, and R. Schmutzler, Chem. Ber., 1978, 111, 3105 .

8 For detailed $a b$ initio SCF calculations on parent imino- and methylene-phosphane see G. Tranquier, J. Am. Chem. Soc., 1982, 104, 6969; D. Gonbeau, G. Pfister-Guillouzo, and J. Barrans, Can. J. Chem., 1983, 61, 1371; D. J. Bruna, V. Krumbach, and S. D. Peyerimhoff, ibid., in the press. 